CLINICAL STUDY

\title{
Circulating endothelial cells are elevated in patients with type 1 diabetes mellitus
}

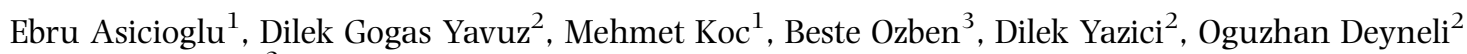 \\ and Sema Akalin ${ }^{2}$ \\ ${ }^{1}$ Division of Nephrology, Department of Internal Medicine, ${ }^{2}$ Division of Endocrinology and Metabolism, Department of Internal Medicine and ${ }^{3}$ Department \\ of Cardiology, Marmara University School of Medicine, Tophanelioglu Caddesi, No: 15/10, Altunizade, Uskudar, Istanbul 32622, Turkey \\ (Correspondence should be addressed to E Asicioglu; Email: easicioglu@yahoo.com)
}

\begin{abstract}
Objective: Circulating endothelial cells (CECs) have emerged as vascular damage markers and are increased in type 2 diabetic patients. Since type 1 diabetes is associated with vascular damage, we hypothesized high CEC numbers in this patient population.

Methods: Thirty-nine patients with type 1 diabetes and 39 controls were included. CECs were isolated using anti-CD146-coated Dynabeads, stained with Ulex lectin-1, and counted by fluorescence microscopy. Endothelial function was measured as flow-mediated dilation (FMD). Thiobarbituric acid reactive substances (TBARS), total glutathione levels (GSH), and paraoxonase (PON) activity levels were measured as oxidative stress markers.

Results: Patients with type 1 diabetes mellitus had higher number of CECs $(7.46 \pm 5.37$ vs 2.13 \pm 1.13 cells $/ \mathrm{ml}, P<0.001)$, lower FMD $(7.87 \pm 2.19$ vs $12.06 \pm 2.34 \%, P<0.001)$, higher TBARS $(4.94 \pm 1.20$ vs $3.07 \pm 0.75 \mathrm{nmol} / \mathrm{MDA}, \quad P<0.001)$, lower GSH $(206.12 \pm 98.06$ vs 353.61 $\pm 68.45 \mu \mathrm{M}, P<0.001)$, and lower PON activity levels $(89.10 \pm 17.82$ vs $127.65 \pm 29.01 \mathrm{U} / \mathrm{l}$, $P<0.001)$ as compared to controls.

There was positive correlation between CEC numbers and HbAlc levels $(r=0.49, P=0.002)$. CECs and fasting glucose levels were not correlated. There was no correlation between the number of CECs and FMD. Furthermore, there were no correlations between the number of CECs and TBARS, GSH and PON activity levels. Multiple regression analysis showed that HbAlc levels $\left(r^{2}=0.40, P<0.009\right)$ were associated with CEC numbers.

Conclusion: CECs are elevated in patients with type 1 diabetes mellitus reflecting endothelial damage. This increase is dependent on long-term glucose control.
\end{abstract}

European Journal of Endocrinology 162 711-717

\section{Introduction}

Endothelial dysfunction has been documented in patients with diabetes and plays a key role in the pathogenesis of diabetic vascular disease, which is the principal cause of mortality and morbidity in these patients (1-5). Hypertension and hyperlipidemia are some of the well-known risk factors for the development of endothelial dysfunction. However, hyperglycemia itself can cause endothelial injury and dysfunction through several mechanisms (6-12). Exposure of endothelial cells to high glucose levels increases oxidative stress. This results in enhanced generation of reactive oxygen species and reduction of antioxidant reserves (13-16). Hyperglycemia also increases the production of advanced glycation end products as well as the activation of the protein kinase $\mathrm{C}$ and polyol pathways (13-16). These hyperglycemia-mediated mechanisms disrupt cell cycling, which in turn causes inhibition of cell proliferation and migration as well as an increase in the apoptosis of endothelial cells (17-21).

In recent years, circulating endothelial cells (CECs) have emerged as markers of vascular damage. While present in very small numbers in healthy individuals, their number increases dramatically in diseases with vascular damage, such as cardiovascular disease, specific infections, vasculitis, and type 2 diabetes (22-29). Since type 1 diabetes is associated with endothelial dysfunction and vascular damage, we hypothesized increased number of CECs in this patient population. We measured the number of CECs, flow-mediated dilation (FMD), and oxidative stress markers thiobarbituric acid reactive substances (TBARS), total glutathione levels (GSH), and serum paraoxonase (PON) activity in type 1 diabetes and healthy subjects. We further attempted to determine the correlation between the number of CECs and markers of endothelial dysfunction, oxidative stress and glucose control. 


\section{Methods}

\section{Patients and controls}

The study was approved by the ethics committee of Marmara University Medical School and was carried out in accordance with the Declaration of Helsinki. All subjects gave informed consent for participation. Thirtynine type 1 diabetic patients and healthy controls were included in the study. Inclusion criteria for the diabetic group were previous diagnosis of type 1 diabetes for at least 1 year and age between 18 and 60 years. Healthy individuals with normal fasting blood glucose levels who were at least 18 years old were included as the control group. Exclusion criteria for both groups were as follows: i) any systemic disease that is known to cause endothelial dysfunction such as systemic hypertension (defined according to the JNC-7 criteria), hyperlipidemia (defined according to the NCEP-ATP 3 criteria), coronary artery disease, peripheral vascular disease, carotid artery disease, inflammatory or infectious processes within the last 3 months, and malignancy $(30,31)$, ii) invasive procedures within the last month, iii) abnormal renal/hepatic biochemical values, iv) medications that can disrupt endothelial function such as aspirin, antilipidemic agents, angiotensin converting enzyme (ACE) inhibitors, and angiotensin receptor blockers (ARBs), v) smoking, and vi) pregnancy and lactation.

\section{Isolation and enumeration of CECs}

In order to isolate and enumerate CECs, we used the study protocol described by Woywodt et al. (32). This technique depends on the use of paramagnetic particles coated with antibodies directed against the CD146 molecule found on endothelial cells.

Blood was obtained by nontraumatic venipuncture and collected in two $7.5 \mathrm{ml}$ EDTA tubes. The first tube was discarded to avoid false positive results caused by dislodging of endothelial cells during venipuncture. One milliliter of blood from the second tube was diluted in $1 \mathrm{ml}$ BSA/PBS buffer (0.1\% BSA in PBS) and blocked by $20 \mu \mathrm{Fc}$ receptor (Miltenyi, Gladbach, Germany) for $10 \mathrm{~min}$ at $4{ }^{\circ} \mathrm{C}$. Then, $50 \mu \mathrm{l}$ anti-CD146-coated M-450 paramagnetic particles (Dynabeads, Dynal, Norway) were added and mixed thoroughly. The sample was mixed in a head-over-head mixer for $30 \mathrm{~min}$ at $4{ }^{\circ} \mathrm{C}$ and washed four times with PBS/BSA buffer in front of a magnet (Dynal, MPC-L, Dynal, Norway). Then, these isolated cells are further stained with a specific endothelial cell marker. Fifty microliters of a $2 \mathrm{mg} / \mathrm{ml}$ FITC-coupled UEA-1 solution (Sigma-Aldrich) were added and incubated for half an hour in darkness. Then, the sample was washed twice and suspended in $200 \mu \mathrm{l}$ PBS solution. Cells were counted by fluorescence microscopy using a Nageotte chamber (Fig. 1). CECs were identified according to the criteria defined by Woywodt et al. Cells that were $20-50 \mu \mathrm{m}$ in length and

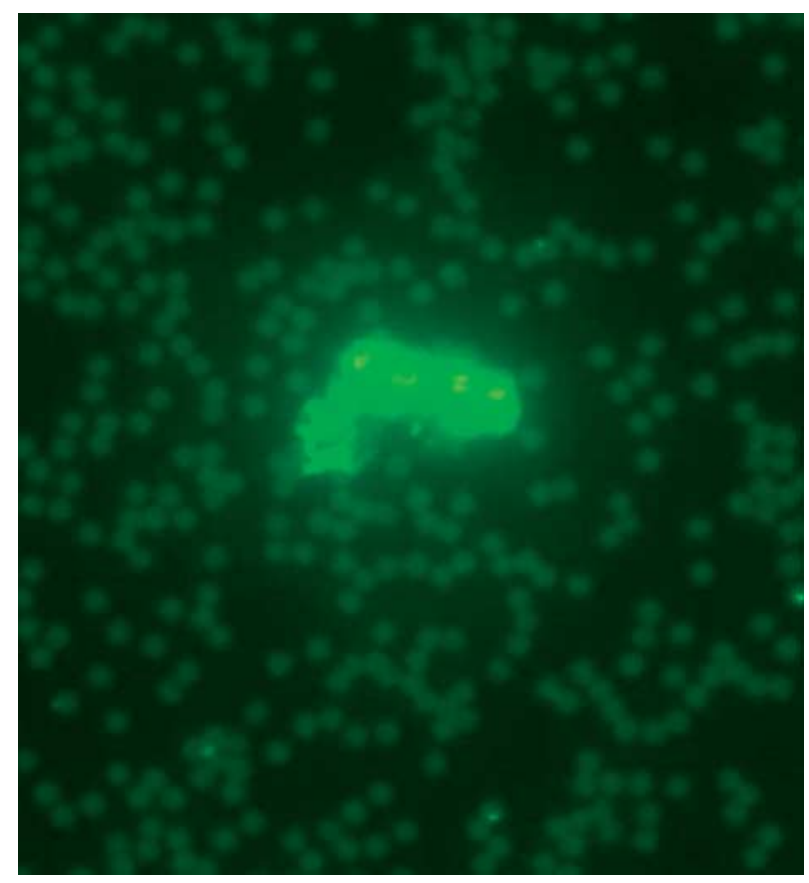

Figure 1 Circulating endothelial cell (CEC) under fluorescence microscopy.

covered with at least four magnetic beads staining positive with FITC-UEA-1 were accepted as endothelial cells (32). To serve as positive controls, various concentrations of human umbilical vein endothelial cells were diluted in blood from healthy volunteers, and recovery was $>90 \%$.

\section{Measurement of FMD}

High-resolution ultrasound was used to assess changes in the diameter of the brachial artery. Measurements were taken in the fasting state before obtaining blood samples with the subjects resting for at least $10 \mathrm{~min}$ in the supine position. Images were obtained by a single operator using a 10-MHz vascular ultrasound probe (Vingmed Ultrasound, System 5, Horten, Norway). The brachial artery was scanned 10-15 cm above the antecubital fossa, and the transducer was kept in a fixed position throughout the procedure. After baseline measurements of the diameter and the flow velocity of the brachial artery, a blood pressure cuff placed around the forearm was inflated to $300 \mathrm{mmHg}$ and released after $5 \mathrm{~min}$. The diameter and the flow velocity were measured again 45-60 s after cuff release. Then, the brachial artery was allowed to return to baseline values over a period of $15 \mathrm{~min}$ for the measurement of endothelium-independent dilation. In order to measure endothelium-independent dilation, $400 \mu \mathrm{g}$ sublingual glyceryl trinitrate (GTN) was applied, and the measurements were repeated after $3 \mathrm{~min}$. Percent FMD and percent GTN were calculated as the percent changes in diameter relative to the baseline measurements. 
Measurements were done at end diastole simultaneously with the R-wave on a continuously recorded electrocardiogram. The diameters at three cardiac cycles were analyzed for each measurement, and the average value was used. The intra-observer variability was $<5 \%$.

\section{Measurement of TBARS}

Lipid peroxidation was measured by the formation of TBARS using 1,1,3,3-tetraethoxypropane as standard. After the serum was mixed with thiobarbituric acid, it was heated at $100{ }^{\circ} \mathrm{C}$ for $15 \mathrm{~min}$. The red pigment produced was extracted with $n$-butanol-pyridine mixture and was estimated by absorbance at $532 \mathrm{~nm}$ (33). Intra- and interassay coefficients of variation were 4.8 and $5.1 \%$ respectively.

\section{Measurement of PON activity}

The PON activity was determined spectrophotometrically using paraoxon as the substrate in a Tris buffer containing $\mathrm{NaCl}$ and $\mathrm{CaCl}_{2}$, and measured by increases in the absorbance at $405 \mathrm{~nm}$ due to the formation of 4-nitrophenol. After the addition of the serum sample, the reaction was monitored for $5 \mathrm{~min}$ at $25^{\circ} \mathrm{C}$, and PON activity was expressed as units per liter of serum (U/l) (34).

\section{Measurement of GSH}

GSH was measured in blood plasma as descried by $\mathrm{Hu}$ et al. (35). Plasma was mixed with Tris-EDTA and measured at an absorbance of $412 \mathrm{~nm}$. This value was called A1. Then, di-thiobis nitrobenzoic acid was added to the mixture and incubated for $15 \mathrm{~min}$ in the darkness. This was again measured at an absorbance of $412 \mathrm{~nm}$, yielding A2. The GSH was calculated from the formula $(\mathrm{A} 2-\mathrm{A} 1) \times 1.57$ and expressed as $\mu \mathrm{M}$.

\section{Statistical analysis}

All calculations were done using SPSS for Windows version 11.0 (SPSS, Chicago, IL, USA). Data were expressed as means \pm s.D. Comparisons between the groups were done by Mann-Whitney U test. Spearman's rank correlation analysis was utilized to determine the relation between the number of CECs and markers of endothelial dysfunction, oxidative stress and glucose control. Stepwise multiple regression analysis was performed to define the predictors of CEC number, and $P<0.05$ was considered statistically significant at all times.

\section{Results}

Demographic and clinical features of study groups are summarized in Tables 1-3.
Table 1 Demographic characteristics of patients and healthy controls. Values are expressed as mean \pm S.D.

\begin{tabular}{lll}
\hline & $\begin{array}{l}\text { Type 1 diabetic } \\
\text { patients }(n=39)\end{array}$ & \multicolumn{1}{c}{$\begin{array}{c}\text { Healthy controls } \\
(n=39)\end{array}$} \\
\hline Age (years) & $31.74 \pm 8.53$ & $29.23 \pm 4.64$ \\
Gender (F/M) & $15 / 24$ & $26 / 13$ \\
Duration of & $9.27 \pm 6.12$ & - \\
$\quad$ diabetes (years) & & \\
Retinopathy & $2 / 39$ & - \\
Nephropathy & $4 / 39$ & - \\
Neuropathy & $2 / 39$ & - \\
BMI (kg/m $\left.{ }^{2}\right)$ & $24.23 \pm 3.12$ & $22.93 \pm 2.79$ \\
Waist-to-hip ratio & $0.80 \pm 0.05$ & $0.80 \pm 0.07$ \\
Systolic BP (mmHg) & $109.76 \pm 19.86$ & $109.32 \pm 8.18$ \\
Diastolic BP (mmHg) & $72.90 \pm 9.05$ & $77.70 \pm 4.50^{*}$ \\
\hline
\end{tabular}

BMI, body mass index; BP, blood pressure. ${ }^{\star} P<0.05$ versus type 1 diabetic patients group.

Age, body mass index, waist-to-hip ratio, and systolic blood pressure measurements were similar between the two groups. The number of female controls was significantly higher compared to diabetic patients. While diastolic blood pressure measurements were statistically different between the two groups, they were still within the normal range (Table 1). Fasting glucose and HbAlc values are significantly higher in the diabetic group. Total cholesterol, low density lipoprotein cholesterol, high density lipoprotein cholesterol, triglycerides, and creatinine values are not statistically different between the two groups (Table 2).

Patients with type 1 diabetes mellitus had higher CECs $(7.46 \pm 5.37$ cells $/ \mathrm{ml})$ compared to healthy controls $(2.13 \pm 1.13$ cells $/ \mathrm{ml} ; P<0.001)$. FMD (\%) was significantly lower in the diabetic group $(7.87 \pm 2.19$ vs $12.06 \pm 2.34, P<0.001)$. Patients with type 1 diabetes had higher TBARS levels $(4.94 \pm 1.20$ vs 3.07 $\pm 0.75 \mathrm{nmol} / \mathrm{MDA}, \quad P<0.001)$, lower GSH levels $(206.12 \pm 98.06$ vs $353.61 \pm 68.45 \mu \mathrm{M}, P<0.001)$, and lower PON activity (89.10 \pm 17.82 vs $127.65 \pm 29.01 \mathrm{U} / \mathrm{l}$, $P<0.001$ ) compared to healthy controls (Table 3).

There were negative correlations between FMD (\%) and fasting glucose $(r=-0.40, P<0.001)$, HbAlc $(r=-0.56, P<0.001)$ and TBARS levels $(r=-0.68$, $P<0.001)$. There were significant positive correlations

Table 2 Biochemical data of study groups. Values are expressed as mean \pm S.D.

\begin{tabular}{lcc}
\hline & $\begin{array}{c}\text { Type 1 } \\
\text { diabetic patients } \\
(n=39)\end{array}$ & $\begin{array}{c}\text { Healthy } \\
\text { controls } \\
(n=39)\end{array}$ \\
\hline Fasting glucose (mg/dl) & $181.75 \pm 98.16$ & $83.68 \pm 12.86^{*}$ \\
HbAlc $(\%)$ & $7.42 \pm 1.69$ & $4.58 \pm 0.31^{*}$ \\
Total cholesterol (mg/dl) & $151.89 \pm 44.47$ & $145.35 \pm 45.66$ \\
LDL cholesterol (mg/dl) & $95.63 \pm 31.55$ & $93.97 \pm 35.13$ \\
HDL cholesterol (mg/dl) & $37.00 \pm 10.99$ & $38.51 \pm 11.28$ \\
Triglycerides (mg/dl) & $81.37 \pm 44.68$ & $64.14 \pm 29.47$ \\
Creatinine $(\mathrm{mg} / \mathrm{dl})$ & $0.92 \pm 0.26$ & $0.91 \pm 0.17$ \\
\hline
\end{tabular}

${ }^{\star} P<0.001$ versus type 1 diabetic patients group. 
Table 3 Measurements of CECs, FMD, TBARS, GSH, and PON. Values are expressed as mean \pm S.D.

\begin{tabular}{lcc}
\hline & $\begin{array}{c}\text { Type 1 diabetic } \\
\text { patients } \\
(n=39)\end{array}$ & $\begin{array}{c}\text { Healthy } \\
\text { controls } \\
(n=39)\end{array}$ \\
\hline Number of CECs (cells/ml) & $7.46 \pm 5.37$ & $2.13 \pm 1.13^{*}$ \\
FMD $(\%)$ & $7.87 \pm 2.19$ & $12.06 \pm 2.34^{*}$ \\
TBARS (nmol/MDA) & $4.94 \pm 1.20$ & $3.07 \pm 0.75^{*}$ \\
GSH $(\mu \mathrm{M})$ & $206.12 \pm 98.06$ & $353.61 \pm 68.45^{*}$ \\
PON $(\mathrm{U} / \mathrm{l})$ & $89.10 \pm 17.82$ & $127.65 \pm 29.01^{*}$ \\
\hline
\end{tabular}

CECs, circulating endothelial cells; FMD, flow-mediated dilatation; TBARS, thiobarbituric acid reactive substances; GSH, total glutathione levels; PON, serum paraoxonase activity. ${ }^{*} P<0.001$ versus type 1 diabetic patients group.

between FMD $(\%)$ and GSH $(r=0.51, P<0.001)$ as well as PON activity levels $(r=0.62, P<0.001)$.

There was a significant positive correlation between the number of CECs and HbAlc levels $(r=0.49$, $P=0.002$; Fig. 2). However, CEC numbers and fasting glucose levels were not correlated. There was no correlation between the number of CECs and FMD. Furthermore, there were no correlations between the number of CECs and markers of oxidative stress, measured as TBARS levels, GSH levels, and PON activity (data not shown). Multiple regression analysis showed that HbAlc levels $\left(r^{2}=0.40, P<0.009\right)$ were associated with CEC numbers.

\section{Discussion}

In recent years, measurement of CECs has emerged as a new method of determining endothelial function. While present in very small numbers in healthy individuals, their number increases dramatically in diseases with vascular damage, such as cardiovascular diseases, vasculitis, hemodialysis patients, specific infections, and type 2 diabetes (22-29, 36). Furthermore, these numbers correlate with disease activity and are closely related to the severity of endothelial lesions $(27,28)$. In this study, we found that patients with type 1 diabetes mellitus had a significantly increased number of CECs as compared to healthy controls. Furthermore, the CEC numbers were positively correlated with $\mathrm{HbAlc}$ levels.

Prolonged hyperglycemia impairs endothelial cell function, resulting in endothelial dysfunction.

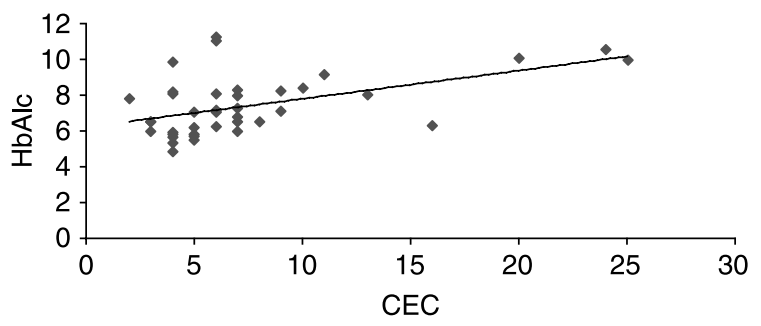

Figure 2 Correlation between CECs and HbAlc levels $(r=0.49$, $P=0.002)$.
Our results were in accordance with this, showing a strong correlation between the number of CECs and the levels of HbAlc. To our knowledge, this is the first study to show a correlation between CEC numbers and HbAlc levels. In another study by McClung et al., they showed an increase in the number of CECs in type 2 diabetic patients but were not able to show a correlation with the levels of HbAlc (29). We believe that this was due to the patient population studied. The incidence of coronary artery disease, hypertension, and hyperlipidemia is higher in type 2 diabetic patients, all having the potential to cause endothelial dysfunction and increased CEC numbers $(23,37,38)$. Furthermore, patients using ACE inhibitors and statins, medications known to alter endothelial function, were included. Patients with type 2 diabetes mellitus also have insulin resistance, which contributes to inflammation, and this inflammation-mediated endothelial dysfunction is substantially less likely to be correlated with HbAlc. In this study, we excluded patients with known hypertension, hyperlipidemia, or coronary artery disease. Patients taking medications known to affect endothelial function were further excluded. We believe that the increase in CEC numbers in our study reflects endothelial dysfunction solely caused by hyperglycemia and therefore is correlated with the levels of HbAlc.

In our study, diabetic patients had higher TBARS levels as well as lower GSH, PON activity, and percent FMD as compared to healthy controls, which is consistent with previous reports in literature $(6,39-41)$. FMD (\%) showed negative correlation with fasting glucose, HbAlc, and TBARS levels, while positively correlated with GSH and PON activity levels. Our data show that endothelial dysfunction measured as percent FMD and oxidative stress coexist in diabetes and are closely related. However, there were no correlations between CEC numbers and TBARS, GSH, PON activity and percent FMD. We believe that this shows that the increase in CEC number in this patient population may be a direct consequence of the effect of hyperglycemia on vasculature such as increased endothelial cell apoptosis and sloughing rather than endothelial damage caused by oxidative stress. Several studies have shown that hyperglycemia increases endothelial cell apoptosis through the production of peroxynitrate $(17$, 20). Hyperglycemia also prolongs endothelial cell cycle and inhibits proliferation $(19,21,42)$. Lorenzi et al. have shown that chronic hyperglycemia but not acute hyperglycemia prolongs the endothelial cell cycle (19). This may explain why CEC numbers in our study were correlated with HbAlc levels, while fasting glucose levels were not correlated. Hyperglycemia-induced oxidative stress also increases detachment of the endothelial cells from the extracellular matrix, which probably contributes to increased CEC numbers in diabetic patients (43). Another possible mechanism for increased endothelial cell sloughing may be the heme oxygenase (HO) system. Abraham et al. have shown that 
the number of detached endothelial cells increases in diabetic rats and in hyperglycemic animals underexpressing HO-1, while decreasing in diabetic animals overexpressing HO-1 compared with controls (44). All these studies show that hyperglycemia, through several different mechanisms, decreases growth and migration of endothelial cells, while enhancing apoptosis and cell sloughing (17-21, 42-44).

In this study, the number of CECs in the diabetic cohort is less than those reported in patients with type 2 diabetes mellitus and other inflammatory conditions. There are several possible explanations for this discrepancy. Even though a consensus has been reached in enumerating CECs with immunomagnetic isolation, some studies have used different techniques with this method $(23,26,32)$. There are also studies that count CECs with flow cytometry (22). Another possible explanation is the association between disease activity, inflammation, endothelial lesions, and CEC number. In a recent study, patients with active anti-neutrophil cytoplasmic antibody (ANCA)-positive granulomatous vasculitis had significantly higher CEC numbers as compared to those with limited disease or remission (45). Similarly, other studies have reported a correlation between CEC numbers, and markers of inflammation and endothelial dysfunction such as C-reactive protein (CRP) and von Willebrand factor (vWf). Since acute myocardial infarction, unstable angina, vasculitis, and infections are associated with more inflammation than diabetes mellitus, it may be safe to assume a smaller number of CECs in this patient population. Patients with type 2 diabetes mellitus have a higher incidence of coronary artery disease, hypertension, and hyperlipidemia as compared to type 1 diabetic patients as well as insulin resistance, all having the potential to cause more inflammation, endothelial dysfunction, and thus higher CEC numbers $(23,37,38)$. Insulin resistance observed in type 2 diabetic patients may also account for greater endothelial damage and higher CEC numbers in this population.

Even though CECs are increased in certain conditions, it is not lear whether this increase is due to endothelial cell sloughing caused by vascular damage or an increase in endothelial progenitor cells derived from the bone marrow. However, we know that at least in hyperglycemic states, endothelial cell apoptosis and cell sloughing increase. Furthermore, prior studies have demonstrated decreased numbers of bone marrowderived circulating endothelial progenitor cells in conditions associated with endothelial dysfunction $(46,47)$. Therefore, it is logical to assume that the increase in CEC number is due to endothelial cell sloughing caused by vascular damage.

CECs are not merely markers of ongoing endothelial damage; they are also predictors of future cardiovascular events in certain patient populations $(48,49)$. The value of CECs predicting future cardiovascular events in diabetic patients is unknown. The close relationship between oxidative stress markers and CEC number may support this notion in diabetic patients. In the future, a much larger prospective study can be designed to determine whether the increase in CEC number is indicative of an adverse outcome in this patient population. Bone marrow-derived circulating progenitor cells can be measured by flow cytometry in the same patient population in order to determine the origin of CECs with certainty.

In conclusion, we have demonstrated that the number of CECs is elevated in patients with type 1 diabetes reflecting endothelial damage, and this increase is also directly dependent on long-term glucose control.

\section{Declaration of interest}

The authors declare that there is no conflict of interest that could be perceived as prejudicing the impartiality of the research reported.

\section{Funding}

This work was supported by grants from 'Eczacıbaşı Scientific Research and Award Fund' and 'The Marmara University Scientific Research Committee'.

\section{References}

1 Celermajer DS. Endothelial dysfunction: does it matter? Is it reversible? Journal of the American College of Cardiology $1997 \mathbf{3 0}$ 325-333.

2 Brownlee M. Biochemistry and molecular cell biology of diabetic complications. Nature $2001414813-820$.

3 Swerdlow AJ \& Jones ME. Mortality during 25 years of follow-up of a cohort with diabetes. International Journal of Epidemiology 1996 25 1250-1261.

4 Ceriello A, Esposito K, Ihnat M, Thorpe J \& Giugliano D. Long-term glycemic control influences the long-lasting effect of hyperglycemia on endothelial function in type 1 diabetes. Journal of Clinical Endocrinology and Metabolism 200994 2751-2756.

5 Sibal L, Aldibbiat A, Agarwal SC, Mitchell G, Oates C, Razvi S, Weaver JU, Shaw JA \& Home PD. Circulating endothelial progenitor cells, endothelial function, carotid intima-media thickness and circulating markers of endothelial dysfunction in people with type 1 diabetes without macrovascular disease or microalbuminuria. Diabetologia 200952 1464-1473.

6 Johnstone MT, Creager SJ, Scales KM, Cusco JA, Lee BK \& Creager MA. Impaired endothelium-dependent vasodilation in patients with insulin-dependent diabetes mellitus. Circulation 199388 2510-2516.

7 Meeking DR, Cummings MH, Thorne S, Donald A, Clarkson P, Crook JR, Watts GF \& Shaw KM. Endothelial dysfunction in type 2 diabetic subjects with and without microalbuminuria. Diabetic Medicine 199916 841-847.

8 Jarvisalo MJ, Raitakari M, Toikka JO, Putto-Laurila A, Rontu R, Laine S, Lehtimäki T, Rönnemaa T, Viikari J \& Raitakari OT. Endothelial dysfunction and increased arterial intima-media thickness in children with type 1 diabetes. Circulation 2004109 1750-1755.

9 Clarkson P, Celermajer DS, Donald AE, Sampson M, Sorensen KE, Adams M, Yue DK, Betteridge DJ \& Deanfield JE. Impaired vascular reactivity in insulin-dependent diabetes mellitus is related to disease duration and low density lipoprotein cholesterol levels. Journal of the American College of Cardiology 199628 573-579. 
10 Dogra G, Rich L, Stanton K \& Watts GF. Endothelium-dependent and independent vasodilation studies at normoglycaemia in type I diabetes mellitus with and without microalbuminuria. Diabetologia 200144 593-601.

11 Henry RM, Ferreira I, Kostense PJ, Dekker JM, Nijpels G, Heine RJ, Kamp O, Bouter LM \& Stehouwer CD. Type 2 diabetes is associated with impaired endothelium-dependent, flow-mediated dilation, but impaired glucose metabolism is not: the Hoorn Study. Atherosclerosis 2004174 49-56.

12 Makimattila S, Liu ML, Vakkilainen J, Schlenzka A, Lahdenpera S, Syvanne M, Mäntysaari M, Summanen P, Bergholm R, Taskinen MR \& Yki-Järvinen H. Impaired endothelium-dependent vasodilation in type 2 diabetes. Relation to LDL size, oxidized LDL, and antioxidants. Diabetes Care 199922 973-981.

13 Giugliano D, Ceriello A \& Paolisso G. Oxidative stress and diabetic vascular complications. Diabetes Care 199619 257-267.

14 Stehouwer CD, Lambert J, Donker AJ \& van Hinsbergh VW. Endothelial dysfunction and pathogenesis of diabetic angiopathy. Cardiovascular Research 199734 55-68.

15 Mabley JG \& Soriano FG. Role of nitrosative stress and poly(ADPribose) polymerase activation in diabetic vascular dysfunction. Current Vascular Pharmacology 20053 247-252.

16 King GL \& Loeken MR. Hyperglycemia-induced oxidative stress in diabetic complications. Histochemistry and Cell Biology 2004122 333-338.

17 Zou MH, Shi C \& Cohen RA. High glucose via peroxynitrite causes tyrosine nitration and inactivation of prostacyclin synthase that is associated with thromboxane/prostaglandin $\mathrm{H}(2)$ receptormediated apoptosis and adhesion molecule expression in cultured human aortic endothelial cells. Diabetes 200251 198-203.

18 Baumgartner-Parzer SM, Wagner L, Pettermann M, Grillari J, Gessl A \& Waldhausl W. High-glucose-triggered apoptosis in cultured endothelial cells. Diabetes 199544 1323-1327.

19 Lorenzi M, Nordberg JA \& Toledo S. High glucose prolongs cellcycle traversal of cultured human endothelial cells. Diabetes 1987 36 1261-1267.

$20 \mathrm{Du}$ X, Stocklauser-Farber K \& Rosen P. Generation of reactive oxygen intermediates, activation of NF-kappaB, and induction of apoptosis in human endothelial cells by glucose: role of nitric oxide synthase? Free Radical Biology \& Medicine 199927 752-763.

21 Nakao-Hayashi J, Ito H \& Kawashima S. An oxidative mechanism is involved in high glucose-induced serum protein modification causing inhibition of endothelial cell proliferation. Atherosclerosis $19929789-95$.

22 Khan SS, Solomon MA \& McCoy JP Jr. Detection of circulating endothelial cells and endothelial progenitor cells by flow cytometry. Cytometry. Part B, Clinical Cytometry 200564 1-8.

23 Mutin M, Canavy I, Blann A, Bory M, Sampol J \& Dignat-George F. Direct evidence of endothelial injury in acute myocardial infarction and unstable angina by demonstration of circulating endothelial cells. Blood 199993 2951-2958.

24 George F, Brouqui P, Boffa MC, Mutin M, Drancourt M, Brisson C, Raoult D \& Sampol J. Demonstration of Rickettsia conorii-induced endothelial injury in vivo by measuring circulating endothelial cells, thrombomodulin, and von Willebrand factor in patients with Mediterranean spotted fever. Blood 199382 2109-2116.

25 Percivalle E, Revello MG, Vago L, Morini F \& Gerna G. Circulating endothelial giant cells permissive for human cytomegalovirus (HCMV) are detected in disseminated HCMV infections with organ involvement. Journal of Clinical Investigation 199392 663-670.

26 Nakatani K, Takeshita S, Tsujimoto H, Kawamura Y, Tokutomi T \& Sekine I. Circulating endothelial cells in Kawasaki disease. Clinical and Experimental Immunology 2003131 536-540.

27 Clancy R, Marder G, Martin V, Belmont HM, Abramson SB \& Buyon J. Circulating activated endothelial cells in systemic lupus erythematosus: further evidence for diffuse vasculopathy. Arthritis and Rheumatism 200144 1203-1208.

28 Woywodt A, Streiber F, de Groot K, Regelsberger H, Haller H \& Haubitz M. Circulating endothelial cells as markers for ANCAassociated small-vessel vasculitis. Lancet $2003 \mathbf{3 6 1} 206-210$.
29 McClung JA, Naseer N, Saleem M, Rossi GP, Weiss MB, Abraham NG \& Kappas A. Circulating endothelial cells are elevated in patients with type 2 diabetes mellitus independently of $\mathrm{HbA}(1)$ c. Diabetologia $2005 \mathbf{4 8} 345-350$.

30 Chobanian AV, Bakris GL, Black HR, Cushman WC, Green LA, Izzo JL Jr, Jones DW, Materson BJ, Oparil S, Wright JT Jr \& Roccella EJ. National Heart, Lung, and Blood Institute Joint National Committee on Prevention, Detection, Evaluation, and Treatment of High Blood Pressure; National High Blood Pressure Education Program Coordinating Committee. The Seventh Report of the Joint National Committee on Prevention, Detection, Evaluation, and Treatment of High Blood Pressure: the JNC 7 report. Journal of the American Medical Association 2003289 2560-2572.

31 National Cholesterol Education Program (NCEP) Expert Panel on Detection, Evaluation, and Treatment of High Blood Cholesterol in Adults (Adult Treatment Panel III). Third Report of the National Cholesterol Education Program (NCEP) Expert Panel on Detection, Evaluation, and Treatment of High Blood Cholesterol in Adults (Adult Treatment Panel III) final report. Circulation 2002106 3143-3421.

32 Woywodt A, Blann AD, Kirsch T, Erdbruegger U, Banzet N, Haubitz M \& Dignat-George F. Isolation and enumeration of circulating endothelial cells by immunomagnetic isolation: proposal of a definition and a consensus protocol. Journal of Thrombosis and Haemostasis 20064 671-677.

33 Yagi K. Assay for blood plasma or serum. Methods in Enzymology $1984105328-331$.

34 Abbott CA, Mackness MI, Kumar S, Boulton AJ \& Durrington PN. Serum paraoxonase activity, concentration, and phenotype distribution in diabetes mellitus and its relationship to serum lipids and lipoproteins. Arteriosclerosis, Thrombosis, and Vascular Biology 199515 1812-1818.

$35 \mathrm{Hu}$ ML. Measurement of protein thiol groups and glutathione in plasma. Methods in Enzymology 1994233 380-385.

36 Koç M, Bihorac A \& Segal MS. Circulating endothelial cells as potential markers of the state of the endothelium in hemodialysis patients. American Journal of Kidney Diseases 200342 704-712.

37 Boos CJ, Lane DA, Karpha M, Beevers DG, Haynes R \& Lip GY. Circulating endothelial cells, arterial stiffness, and cardiovascular risk stratification in hypertension. Chest 2007132 1540-1547.

38 Pirro M, Bagaglia F, Paoletti L, Razzi R \& Mannarino MR. Hypercholesterolemia-associated endothelial progenitor cell dysfunction. Therapeutic Advances in Cardiovascular Disease 20082 329-339.

39 Griesmacher A, Kindhauser M, Andert SE, Schreiner W, Toma C, Knoebl P, Pietschmann P, Prager R, Schnack C \& Schernthaner G. Enhanced serum levels of thiobarbituric-acid-reactive substances in diabetes mellitus. American Journal of Medicine $1995 \mathbf{9 8}$ $469-475$.

40 Jain SK \& McVie R. Effect of glycemic control, race (white versus black), and duration of diabetes on reduced glutathione content in erythrocytes of diabetic patients. Metabolism 199443 306-309.

41 Mackness B, Durrington PN, Boulton AJ, Hine D \& Mackness MI. Serum paraoxonase activity in patients with type 1 diabetes compared to healthy controls. European Journal of Clinical Investigation 200232 259-264.

42 Curcio F \& Ceriello A. Decreased cultured endothelial cell proliferation in high glucose medium is reversed by antioxidants: new insights on the pathophysiological mechanisms of diabetic vascular complications. In Vitro Cellular \& Developmental Biology 199228 787-790.

43 Taniyama Y \& Griendling KK. Reactive oxygen species in the vasculature: molecular and cellular mechanisms. Hypertension 200342 1075-1081.

44 Abraham NG, Rezzani R, Rodella L, Kruger A, Taller D, Li Volti G, Goodman AI \& Kappas A. Overexpression of human heme oxygenase-1 attenuates endothelial cell sloughing in experimental diabetes. American Journal of Physiology. Heart and Circulatory Physiology 2004287 2468-2477. 
45 Woywodt A, Goldberg C, Kirsch T, de Groot K, Erdbruegger U, Haller H \& Haubitz M. Circulating endothelial cells in relapse and limited granulomatous disease due to ANCA associated vasculitis. Annals of Rheumatic Disease 200665 164-168.

46 Hill JM, Zalos G, Halcox JP, Schenke WH, Waclawiw MA, Quyyumi A \& Finkel T. Circulating endothelial progenitor cells, vascular function, and cardiovascular risk. New England Journal of Medicine 2003348 593-600.

47 Vasa M, Fichtlscherer S, Aicher A, Adler K, Urbich C, Martin H, Zeiher AM \& Dimmeler S. Number and migratory activity of circulating endothelial progenitor cells inversely correlate with risk factors for coronary artery disease. Circulation Research 2001 89 1-7.
48 Boos CJ, Soor SK, Kang D \& Lip GY. Relationship between circulating endothelial cells and the predicted risk of cardiovascular events in acute coronary syndromes. European Heart Journal 200728 1092-1101.

49 Koc M, Richards HB, Bihorac A, Ross EA, Schold JD \& Segal MS. Circulating endothelial cells are associated with future vascular events in hemodialysis patients. Kidney International 200567 1078-1083.

Received 28 November 2009

Accepted 29 December 2009 